\title{
QS Subject Focus Summit 2020 on Modern Languages and Linguistics: Languages and migration in a globalized world
}

\author{
Yulia N. Ebzeeva \\ RUDN University \\ Moscow, Russia
}

\begin{abstract}
This article summarizes some of the results of the first QS ${ }^{1}$ Subject Focus Summit on Linguistics and Modern Languages held jointly with the RUDN University on December 15-17, 2020. It provides rationale for the choice of venue of this linguistic forum and analyzes the most relevant topics of discussion, including interdisciplinarity in modern linguistic research, comparative studies of languages and cultures, and intercultural and cross-cultural communication. Participants explored the topics as diverse as the role of linguistics in developing artificial intelligence systems and application of artificial intelligence in linguistic research, the dynamics of languages in minority situations and the efforts in preserving endangered languages. They dwelt on the current state of translation studies and discussed prospects for their future in view of advances in computer technologies, and many others. The articles included in this issue and authored by the Summit participants clearly show that language has become an object of interdisciplinary and transdisciplinary studies. Moreover, the interdisciplinary research paradigm is manifested not only in the convergence of linguistics with other areas of humanities, but also with sciences. This article provides a brief overview of the contributions which present major paradigms of modern linguistics. It highlights the importance of applying computer technologies in linguistic research and emphasizes the necessity to modify language policies in order to preserve minority languages and meet the needs of language education in a multilingual and multicultural environment.
\end{abstract}

Keywords: $R U D N$, QS, modern languages, linguistics, interdisciplinarity, transdisciplinarity

\section{For citation:}

Ebzeeva, Yulia N. 2021. QS Subject Focus Summit 2020 on Modern Languages and Linguistics: Languages and migration in a globalized world. Russian Journal of Linguistics 25 (2). 299-316. DOI: https://doi.org/10.22363/2687-0088-2021-25-2-299-316

${ }^{1}$ QS World University Rankings is viewed as one of the most-widely read university rankings in the world. It comprises the global overall and subject rankings, which name the world's top universities for the study of 51 different subjects and five composite faculty areas. https://www.topuniversities.com/qs-world-university-rankings 
Редакционная статья

\title{
QS саммит 2020 по предметным областям «Современные языки» и «Лингвистика»: Языки и миграция в условиях глобализации
}

\author{
Ю.Н. Эбзеева \\ Российский университет дружбы народов \\ Москва, Россия
}

\begin{abstract}
Аннотация
В данной статье подводятся некоторые итоги первого в истории саммита $\mathrm{QS}^{2}$ по лингвистике и современным языкам, проведенного совместно с РУДН 15-17 декабря 2020 г. Обосновывается выбор места проведения данного лингвистического форума и анализируются наиболее актуальные темы обсуждения, среди которых - междисциплинарность в современных лингвистических исследованиях, сопоставительные исследования языков и культур, межкультурная и кросс-культурная коммуникация, современное состояние и перспективы переводоведческих исследований, лингвистика и искусственный интеллект, динамика языков в миноритарной ситуации и др. Публикуемые в данном выпуске статьи участников саммита убедительно свидетельствуют о том, что язык стал объектом междисциплинарного и трансдисциплинарного изучения, при этом междисциплинарная исследовательская парадигма проявляется не только в сближении лингвистики с другими областями гуманитарного знания, но и в сближении гуманитарного знания с естественно-научным. Делается краткий обзор статей, представленных в данном номере, которые определяют важные парадигмы современных лингвистических исследований. Подчеркивается важность проведения лингвистических исследований с применением компьютерных технологий, ставятся вопросы о необходимости сохранения миноритарных языков, об изменении языковой политики и подходов к языковому образованию в ситуации многоязычной и многокультурной языковой среды.
\end{abstract}

Ключевые слова: РУДН, QS, современные языки, лингвистика, междисциплинарность, трансдисциплинарность

\section{Для цитирования:}

Ebzeeva Y.N. QS Subject Focus Summit 2020 on Modern Languages and Linguistics: Languages and migration in a globalized world. Russian Journal of Linguistics. 2021. Vol. 25. № 2. P. 299-316. DOI: https://doi.org/10.22363/2687-0088-2021-25-2-299-316

This issue is dedicated to the QS Subject Focus Summit on Modern Languages and Linguistics 2020 held online at RUDN University on 15-17 December 2020. The theme of the summit was "Languages and migration in the context of globalization". There are several reasons why RUDN University became a coorganizer of the QS summit on these subject areas.

- Modern languages and linguistics are priority areas at RUDN University.

- RUDN is ahead of other Russian universities in advancing in the international rankings in these disciplines (Ebzeeva et al. 2019). In the QS

${ }^{2}$ Рейтинг QS (QS World University Rankings) - один из самых авторитетных рейтингов университетов в мире. Он включает общие и предметные рейтинги, оценивающие университеты по 51 предмету и пяти предметным областям https://www.topuniversities.com/ qs-world-university-rankings 
university ranking, it occupies the $88^{\text {th }}$ position in Modern Languages and the $101^{\text {st }}$ position in Linguistics.

- With students belonging to 500 ethnicities and coming from 160 countries, RUDN is the most international university in Russia and among the leaders in internationalism in the entire world.

- It has become a tradition at RUDN to pay special attention to the study of languages. All international students study Russian, and all Russian students have an opportunity to study one, two, or three foreign languages out of the 12 offered by the university.

- RUDN University has developed a unique practice: regardless of their field of studies, students can be trained as translators in one or two languages and obtain an additional diploma.

- The university has a unique multilingual environment.

- In order to give an impetus to research, the Institute of Modern Languages, Intercultural Communication and Migration was founded in March 2018 in the framework of the Faculty of Philology. Activities of the new institute embrace several areas, and among them is the study of foreign languages and cultures, including Russian as a foreign language, the training of highly qualified interpreters and simultaneous interpreters in eight languages, research into sociolinguistics and political science, and investigation of migration processes. The first joint FrenchRussian research laboratory "Dynamics of languages in a minority situation" has been created and launched in the framework of the institute. RUDN University and the National Center for Scientific Research of France (CNRS-Centre national de la recherche scientifique) have signed a bilateral research agreement. This is the first agreement CNRS has ever signed with a Russian educational institution in the field of linguistics. The Institute regularly holds round tables, webinars, workshops and lectures. It conducts research on the sociolinguistic situation in the Moscow region, Mordovia, Karelia, Tatarstan and Bashkiria. Some of the field research is done in collaboration with French and Italian colleagues.

- RUDN University is a center for the study of global migration processes. We take part in the work of the Laboratory for the Study of Migration Processes which focuses on socio-cultural adaptation and integration and security issues in the context of migration. The Institute has launched a unique MA programme "Migration Processes and Intercultural Communication" which incorporates a module developed at the University of Mons (Belgium).

- RUDN's motto is "Discover the world at one university". Everyone coming to RUDN University enjoys the atmosphere of multilingualism, cultural diversity, and a combination of tradition and innovation, friendship and harmony. While communication in English dominates, we also support other big and small languages and cultures. The university runs cultural centres affiliated with the countries of the languages we teach and with student communities. We have created thematic linguistic spaces and support multilingual interactive projects and discussion clubs for international students. Thus, RUDN University, being 
multicultural and multilingual, became an ideal venue for the international forum on modern languages and linguistics.

The Summit was attended by more than 500 speakers, researchers in the fields of linguistics and language education, managers of higher educational institutions, experts and researchers in the field of minority language maintenance and preservation, and migration. We are proud that our invitation to participate in the Summit was accepted by well-known scholars from all over the world: Algeria, Australia, China, Estonia, Finland, France, Germany, Israel, Italy, Japan, Kazakhstan, Mexico, Oman, Qatar, Russia, Slovakia, Spain, the USA, the UK, and other countries. The speakers included Anna Wierzbicka, Jean-Marc Devaele, Istvan Kecskes, Laura Alba-Juez, Michael Haugh, Michael McCarthy, Alain Dominique Vio, Robert O'Dowd, Anthony Green, Hino Nobuyuki, Felix Ameka, Tatiana Chernigovskaya, Andrei Kibrik, Vladimir Karasik, Aleкsei Maslov, Vladimir Zorin, Svetlana Ivanova, Olga Leontovich, Vadim Sdobnikov, Marina Solnyshkina, Tatiana Larina, and others. Among the guests attending the opening of the Summit were the Minister of Higher Education and Science of the Russian Federation Valerii Falkov, Deputy Minister of Higher Education and Science of the Russian Federation Petr A. Kucherenko, Founder and Managing Director of QS (Quacquarelli Symonds) Nunzio Quacquarelli, Rector of RUDN University Oleg Yastrebov, and President of RUDN Vladimir Filippov.

The work of the Summit was organized along three main tracks: "Modern Linguistics: Challenges and Responses", "Communication, Identity, National Minorities and Migration", "Languages and Cultures: Teaching and Learning". The speakers compared languages and cultures, explored peculiarities of intercultural and cross-cultural communication and evolution of lingua-cultural identity in migrant communities. Spesial emphasis was given to the dynamics of languages in a minority situation and preservation of endangered languages. Among topical issues were problems of language education, such as creation of barrier-free educational environment, teaching languages for specific purposes, and new challenges confronting educators due to the COVID-19 pandemic. Enthusiasm of the audiences and feedback we received after the Summit encouraged us to continue discussion with the presenters in this issue of the journal.

A significant event of the Summit was the participation of the internationally renowned Polish and Australian linguist and philosopher Anna Wierzbicka who was joined by her colleagues, disciples and followers. Their papers demonstrated the effectiveness and relevance of the theory of "universal semantic primitives" developed and evolving in relation to various languages for 50 years now (Wierzbicka 1972, 1980, 2012, 2020, Goddard \& Wierzbicka 2007, 2021, Gladkova 2019, etc.). Articles in the festschrift in honour of Anna Wierzbicka which the Russian Journal of Linguistics published in $2018^{3}$ continued the exploration of the key concepts of Natural Semantic Metalanguage based on semantic primitives. Their authors implemented Wierzbicka's approach aimed at

\footnotetext{
${ }^{3}$ Russian Journal of Linguistics 22 (3-4) 2018.
} 
analyzing cultural aspects of meaning - keywords of language and culture, and cultural scripts (Gladkova \& Larina 2018a,b). The authors of these issues, as well as the speakers at the Summit, demonstrated a variety of applications of Wierzbicka's theory when exploring cultural semantics and pragmatics, as well as the interaction of language, culture and communication. In the article "Semantic Primitives', fifty years later", which appears in this issue, Wierzbicka reviews the development of the theory and the diversity of its applications proposed in this period. She argues that there is not only a shared "alphabet of human thoughts" but a shared mental language, "Basic Human", with a specifiable vocabulary and grammar which can be a reliable basis for a non-Anglocentric global discourse on universal issues, such as global ethics, the future of the earth, as well as health and wellbeing of all people living on our planet.

Topics related to the interaction of language and culture were widely discussed at the Summit, and this volume follows up on this topic. In the article "Comparing languages and cultures: Parametrization of analytical criteria" Barbara Lewandowska-Tomaszczyk presents arguments in favour of a complex set of areas of reference in cross-linguistic analyses of word meanings. Basing her research on the results of the comparative analysis of the polysemantic English word 'integrity' and its Polish counterparts, she demonstrates the effectiveness of the complex use of linguistic, psychological, cultural and social domains to identify the cultural conceptualizations of the analysed forms in different lingua-cultures.

The talks of the Summit presenters once again convincingly demonstrated that the principles of the organization of scientific knowledge involving the interaction of many areas of research, inter-, multi- and transdisciplinarity are the most important paradigms in the field of linguistics (see, e.g., Mackenzie \& Alba-Juez 2019, Bilá \& Ivanova 2020, Sinelnikova 2020, and others). The combination of inter-, multi- and transdisciplinary approaches enabling researchers to go beyond their disciplines is based on the integration of research methods. When knowledge accumulated in different subject areas is pooled together, new research opportunities surface. This may expand research boundaries and trigger the emergence of new disciplines. The sharing and recombination of the knowhow is becoming an integral principle of linguistic research which came up in the Summit discussions of semantics, ethno-stylistics, language variability, as well as communication and translation.

In this issue, Arto Mustajoki presented a multidimensional model of interaction based on a multidisciplinary approach to communication. The author notes that from the perspective of individual disciplines such as linguistics, sociology, anthropology, psychology, and others, the study of communication can expand our understanding of some aspects of communication, but it can hardly provide a complete picture of this complex process. On the other hand, the Multidimensional Model of Interaction which he proposes creates the basis for a systematic holistic approach to interaction and allows us to apply different methods and view this complex phenomenon from different angles. 
Communication failures which lead to communication breakdowns and may trigger conflicts occur at different levels of communication: interpersonal, intergroup, and even interstate. The problems of intercultural communication have become particularly important and relevant in the context of globalization and migration which encourage intensification of intercultural contacts. To avoid these problems, we have to be aware of the subtleties of the interaction of language, culture and communication. A systematic study and a comprehensive analysis of the communicative behavior of people belonging to different cultures will help us explain the codes and the underlying reasons for various do's and don'ts of the cultures that are not our own. This requires development of new integrative methodologies and promises a variety of applications in different spheres of human activities (see Besemeres \& Wierzbicka 2007, Bromhead \& Ye 2020, Dewaele 2010, Kabakchi \& Proshina 2021, Kecskes 2014, Klyukanov \& Leontovich 2016, Larina 2015, Larina et al. 2016, 2017, Larina \& Ponton 2020, Malyuga \& McCarthy 2018, 2020, Wierzbicka 2003/1991, 2012, 2020 among many others).

Contrastive studies of speech acts and discursive practices in different communicative cultures (Alemi et al., Malyuga \& McCarthy in this issue) reveal social and cultural determinism of communication. They clearly demonstrate that communicative behaviour of people belonging to different cultures differs in similar communicative situations and these differences can only be explained at the interdisciplinary level and with the application of complex methodologies. These studies confirm the interaction of language, culture, cognition and communication and enrich cross-cultural research with new data. The studies in the field of cultural semantics, cross-cultural pragmatics and cultural linguistics have both theoretical and practical implications. Their results can be widely used in second-language teaching, intercultural communication and translation (Bowe et al. 2017, DeCapua \& Wintergerst 2004, Lewis 2019, Pavlovskaya 2021, Savitsky \& Ivanova 2018, etc.).

The state of modern translation studies was also discussed with an emphasis on inter-, multi- and transdisciplinarity. Presenting a large-scale research project on translation ergonomics, Gary Massey offers a model of transdisciplinary research in professional settings and emphasizes the need to move from inter- to transdisciplinarity. Klaudia Bednarova-Gibova examines the prospects and contradictions of modern translation studies related to polydisciplinarity. Although contradictions do exist, it is irrefutable that translation studies are of an interdisciplinary character, which is due to a complex nature of almost all types of translation and translation activities (Sdobnikov 2019: 323).

The interdisciplinary research paradigm does not only manifest itself in the convergence of linguistics with other fields of humanities, resulting in the flourishing of sociolinguistics, psycholinguistics, cultural and cognitive linguistics, and others, but also in the convergence of sciences and humanities, which has given rise to neuro-linguistics, environmental, computer and corpus linguistics. The researchers emphasize that the convergence of different fields of knowledge is one of the most important trends of research and science today (see Sinelnikova 2020). 
The use of information technologies and artificial intelligence in theoretical and applied linguistics is one of the most relevant and promising tracks of interdisciplinary research. Linguistic projects involving the use of computer technologies are proliferating (Alemi \& Haeri 2020, Fuertes-Olivera et al. 2016, Hirschberg \& Manning 2015, Paris et al. 2013, Rapp et al. 2016). The creation of national corpora, participation of linguists in the development of artificial intelligence systems, the use of artificial intelligence in compiling dictionaries, the application of computers and robotics in language education were in the focus of the Summit. The growing interest in this area prompted us to prepare a special issue of the journal devoted to computational linguistics in the near future. In this issue, we have limited ourselves to the article by Salvador Pons Bordería on corpus linguistics and the task of corpus annotating, which is becoming an increasingly important process.

Minority languages, their current state and maintenance is one of the most pressing issues of language policy. Currently, there are dozens, if not hundreds of minority languages and languages in a minority situation. In many cases their dayto-day and even symbolic functioning is difficult or almost impossible. A particular problem is language rights of individuals and groups of endangered-language speakers (e.g., Moskvitcheva \& Viaut 2019, Skutnabb-Kangas 2000, Viaut 2019, 2021). The problem of language death is of a particular concern. Languages have never disappeared as quickly as in our times. The underlying reasons are social, political, economic and cultural ones. Globalization and the necessity for lingua franca as a communication medium for contact speech communities also play a role (e.g., Brenzinger 2007, Crystal 2002, Fishman 2007). Only 600 of the approximately 6,000 existing languages are thought to be non-endangered (Crystal 2002). Today it is no longer a matter of concern for linguists and anthropologists alone, but draws attention of the wide public as well, bringing to the fore people who understand the importance of linguistic and cultural diversity. With the disappearance of a language, a part of culture is lost, as well as the knowledge that was transmitted by this language. For the speakers of endangered languages preserving their mother tongue is a matter of "identity, equality, and social justice" (Guérin \& Yourupi 2017: 2018). The process of language extinction is global and takes place all over the world; unfortunately, Russia is not immune either (e.g., Moskvitcheva 2019, Viaut 2014, 2019, 2021). Is it possible to prevent this process or at least slow it down? In this volume, Andrej A. Kibrik presents the Program for the Preservation and Revitalization of the Languages of Russia proposed by the Institute of Linguistics of the Russian Academy of Sciences. Kibrik gives important humanitarian and scientific reasons for engaging in language preservation. His article examines various approaches to different language situations and puts forward three necessary conditions that must be met in any language revitalization project: the involvement of local activists, administrative and financial support and scientific validity of the methodology. 
Among the issues of applied linguistics referring to the "person - language culture" paradigm, language policies and language education are of primary concern (see, e.g., Aronin \& Yelenevskaya 2021, Kohonen et al. 2014, Polinsky \& Kagan 2007, Protassova \& Yelenevskaya 2020, Ringblom \& Karpava 2020, Zbenovich 2016). Although second-language teaching does not fall into the scope of our journal, in this volume we make an exception and offer readers two articles, the authors of which Hino Nobuyuki, Maria Yelenevskaya and Ekaterina Protassova go far beyond pedagogy. They discuss the interaction of language, ethnicity, identity, culture and education systems. They address approaches to teaching foreign languages which are inseparable from language policies, language ideologies and local sociolinguistic situations. They raise the following questions:

- In the age of globalization and in the situation of linguistic superdiversity, should non-native speakers accommodate themselves to the communicative models of native speakers?

- Does native-speakerism focused on the norms imposed on foreign language learning suppress freedom of thought and expression and in effect, fundamental human rights?

- How is the teaching of world languages, such as English and Russian, changing due to changes in the functions and status of these languages in various countries?

- Do pedagogical methods aimed at achieving 'perfect' command of the studied languages, have a future or it is necessary to take into account students' needs and language repertoires, local sociolinguistic situation and labor market requirements?

These questions seem to require both methodological and linguistic considerations. They will hardly leave any of our readers indifferent because they are directly related to the young generation and, therefore, to our future.

The volume ends with two book reviews that are in tune with the issues discussed at the Summit.

\section{RU}

Данный выпуск посвящен QS саммиту по предметным областям «Современные языки» и «Лингвистика», который проходил в режиме онлайн в РУДН 15-17 декабря 2020 г. Тема саммита - «Языки и миграция в условиях глобализации». РУДН стал со-организатором саммита QS по этим предметным областям не случайно. Этому есть несколько объяснений:

- Современные языки и лингвистика являются приоритетными направлениями развития РУДН.

- РУДН показывает лучшую динамику в России по продвижению в данных предметных рейтингах (Ebzeeva et al. 2019). В международном рейтинге QS он занимает 88-е место по современным языкам и 101-е место по лингвистике. 
- РУДН является самым интернациональным вузом России и одним из самых интернациональных в мире: в нем обучаются студенты 500 национальностей из 160 стран.

- Традиционно в РУДН уделяется особое внимание изучению иностранных языков. Все иностранные студенты изучают русский язык, а все российские студенты имеют возможность изучать один, два и три иностранных языка из 12 предлагаемых.

- В РУДН действует уникальная практика: независимо от специальности каждый студент может параллельно получить диплом переводчика с одного или двух иностранных языков.

- В университете существует уникальная многоязычная среда.

- Чтобы придать импульс научным исследованиям, в марте 2018 г. на базе филологического факультета РУДН был открыт Институт современных языков, межкультурной коммуникации и миграции.

- Деятельность Института включает несколько направлений, в частности изучение иностранных языков и культур (в том числе и русского языка как иностранного), подготовку высококвалифицированных переводчиков, переводчиков-синхронистов с восьми языков, исследование социолингвистических и политологических проблем, системный анализ миграционных процессов. В рамках Института создана и запущена первая совместная франкороссийская исследовательская лаборатория «Динамика языков в миноритарной ситуации». Подписано двустороннее научное соглашение между РУДН и Национальным центром научных исследований Франции (CNRS - Centre national de la recherche scientifique), для которого это первое в области лингвистики соглашение с российской образовательной структурой. На базе Института постоянно проводятся круглые столы, вебинары, рабочие встречи и лекции. Мы проводим исследование социолингвистической ситуации в Подмосковье, Мордовии, Карелии, Татарстане и Башкирии, в том числе полевые исследования с нашими французскими и итальянскими коллегами.

- РУДН - центр изучения глобальных миграционных процессов в мире. Мы принимаем участие в работе Лаборатории изучения миграционных процессов, сосредоточенной на исследовании процессов социокультурной адаптации и интеграции, вопросах безопасности в контексте миграции. В Институте открыта уникальная магистерская программа «Миграционные процессы и межкультурная коммуникация» с включенным модулем Университета Монса (Бельгия).

- Девиз нашего университета - «Открой мир в одном университете». Каждый, кто приезжает в РУДН, погружается в атмосферу многоязычия, культурного многообразия, сочетания традиций и новаторства. У нас царит атмосфера дружбы и согласия. На фоне доминирования английского языка мы поддерживаем как крупнейшие, так и малые языки и культуры. В университете функционируют культурные центры, связанные со странами изучаемых языков и с землячествами. Мы создали тематические лингвистические 
пространства и поддерживаем многоязычные интерактивные проекты, а также дискуссионные клубы для иностранных студентов. Таким образом, РУДН, являясь многоязычной и мультикультурной площадкой, стал идеальным местом для проведения международного форума по современным языкам и лингвистике.

В саммите приняли участие более 500 докладчиков - ученые в области лингвистики и лингвистического образования, менеджеры высшего образования, эксперты и исследователи миноритарных языков и миграции. Мы гордимся тем, что наше приглашение участвовать в саммите приняли известные ученые со всего мира. В качестве ключевых докладчиков выступили ведущие ученые из Австралии, Алжира, Великобритании, Германии, Израиля, Испании, Италии, Казахстана, Катара, Китая, Мексики, Омана, России, Словакии, США, Финляндии, Франции, Эстонии, Японии и других стран. Среди них - Анна Вежбицкая, Жан-Марк Деваеле, Иштван Кечкеш, Лаура Альба-Хуэс, Майкл Хо, Майкл МакКарти, Феликс Амека, Ален Доминик Вио, Роберт О'Дауд, Энтони Грин, Хино Нобуюки, Т.В. Черниговская, А.А. Кибрик, В.И. Карасик, А.А. Маслов, В.Ю. Зорин, С.В. Иванова, О.А. Леонтович, В.В. Сдобников, М.И. Солнышкина, Т.В. Ларина и др. В открытии Саммита приняли участие Министр высшего образования и науки Российской Федерации В. Н. Фальков, зам. министра высшего образования и науки П. А. Кучеренко, основатель и управляющий директор QS (Quacquarelli Symonds) Нунцио Квакварелли, Ректор РУДН О.А. Ястребов и Президент РУДН В.М. Филиппов.

Работа саммита проходила по трем основным направлениям - «Современная лингвистика: проблемы и решения»; «Коммуникация, идентичность, национальные меньшинства, миграция»; «Языки и культуры: преподавание и изучение», в рамках которых обсуждались такие вопросы, как сопоставление языков и культур, межкультурная и кросс-культурная коммуникация, миграция, языковая и культурная идентичность, лингвистика и искусственный интеллект, динамика языков в миноритарной ситуации, проблема сохранения миноритарных языков, безбарьерная среда в образовании, язык для специальных целей, COVID-19 как новый вызов в образовании и др. Живой интерес аудитории и отзывы, которые мы получили после саммита, побудили нас продолжить научный разговор с докладчиками в специальном выпуске журнала.

Значимым событием саммита было участие в нем известного польского и австралийского лингвиста и философа Анны Вежбицкой, а также ее учеников, коллег и последователей. Их доклады продемонстрировали эффективность и востребованность теории «универсальных семантических примитивов» (Wierzbicka 1972, 1980, 2012, 2020, Goddard \& Wierzbicka 2007, 2021, Gladkova 2019 и др.), разрабатываемой уже на протяжении 50 лет применительно к различным языкам. В наших специальных выпусках, посвященных юбилею Анны Вежбицкой ${ }^{4}$, были рассмотрены ключевые положения

${ }^{4}$ Russian Journal of Linguistics 22 (3-4). 2018. 
концепции Естественного Семантического Метаязыка, основанного на семантических примитивах, а также реализация научного подхода А. Вежбицкой, направленного на анализ культурных аспектов смысла - ключевых слов языка и культуры и культурных скриптов (Gladkova \& Larina 2018a,b). Авторы двух юбилейных выпусков, а также докладчики саммита продемонстрировали эффективность применения теории Вежбицкой при рассмотрении вопросов культурной семантики и прагматики, а также взаимодействия языка, культуры и коммуникации. В статье данного выпуска, посвященной пятидесятилетию теории универсальных семантических примитивов, А. Вежбицкая суммирует то, что удалось сделать за эти годы на основе применения данной теории. Она высказывает мысль о том, что существует не только «алфавит человеческого мышления», но и общий ментальный язык «базовый человеческий язык» с определенным словарем и грамматикой, который может стать надежной основой для неанглоцентричного глобального дискурса об общечеловеческих проблемах, таких как глобальная этика, будущее Земли, а также здоровье и благополучие всех людей, живущих на нашей планете.

Вопросы, связанные с исследованием взаимодействия языка и культуры, широко обсуждались на саммите и нашли достойное продолжение в данном выпуске. Барбара Левандовска-Томашчик в статье «Comparing languages and cultures: Parametrization of analytic criteria» приводит убедительные аргументы в пользу междисциплинарного подхода к сопоставительному анализу значений слов. На примере сопоставления многозначного английского слова 'integrity' и его польских лексических соответствий она демонстрирует эффективность комплексного использования лингвистических, психологических, культурных и социальных критериев для выявления особенностей концептуализации того или иного понятия в сознании представителей сопоставляемых лингвокультур.

Доклады участников саммита в очередной раз убедительно продемонстрировали, что междисциплинарность, мультидисциплинарность и трансдисциплинарность, как принципы организации научного знания, предполагающие взаимодействие многих направлений научного исследования, являются важнейшей исследовательской парадигмой в области лингвистики (см. также Alba-Juez \& Larina 2018, Mackenzie \& Alba-Juez 2019, Bila \& Ivanova 2020, Sinelnikova 2020 и др.). Меж-, мульти- и трансдисциплинарный подход, обеспечивающий выход ученых за рамки своих дисциплин, основан на интеграции методов исследования, он соединяет уже имеющиеся знания разных предметных областей, что дает новые исследовательские возможности и перспективы для каждой из областей, способствует появлению новых дисциплин, отраслей знания и расширению их границ. Междисциплинарность / мультидисципплинарность / трансдисциплинарность как неотьемлемые принципы лингвистических исследований отмечались при обсуждении проблем семантики, этностилистики, языковой вариативности, а также коммуникации и перевода. 
В данном выпуске Арто Мустайоки представил многомерную модель взаимодействия, основанную на мультидисциплинарном подходе к коммуникации. Автор отмечает, что исследование коммуникации с позиции различных областей знания - лингвистики, социологии, антропологии, психологии и других - может лишь расширить наше понимание отдельных аспектов коммуникации, но оно не в состоянии дать полной картины этого сложного процесса. Предложенная автором многомерная модель создает основу для системного холистического подхода к взаимодействию и позволяет рассмотреть это сложное явление с различных точек зрения и с применением различных методов.

Коммуникативные неудачи, которые ведут к коммуникативным сбоям и даже конфликтам, происходят на разных уровнях общения - межличностном, межгрупповом и даже межгосударственном. Особую значимость и актуальность в условиях глобализации и миграции, результатом которых явилось расширение межкультурных контактов, приобрели проблемы межкультурной коммуникации. Для их решения необходимо системное исследование взаимодействия языка, культуры, менталитета и коммуникации, всесторонний анализ особенностей коммуникативного поведения представителей различных культур и выявление их причин, а также разработка методологий подобных исследований (см. Besemeres \& Wierzbicka 2007, Bromhead \& Ye 2020, Dewaele 2010, Kecskes 2014, Klyukanov \& Leontovich 2016, Larina 2015, Larina et al. 2016, 2017, Larina \& Ponton 2020, Malyuga \& McCarthy 2018, 2020, Wierzbicka 2003/1991, 2012, 2020 и многие др.).

Исследования, посвященные сопоставительному анализу отдельных речевых актов и дискурсивных практик в разных коммуникативных культуpax (Alemi et al., Malyuga \& McCarthy в этом номере), убедительно свидетельствуют о социальной и культурной детерминированности коммуникативного поведения. Они в очередной раз наглядно иллюстрируют, что объяснить особенности речевого поведения представителей различных культур в однотипных ситуациях общения можно только на междисциплинарном уровне с привлечением знаний культуры и смежных областей и с использованием комплексной методологии. Они являются очередным подтверждением взаимодействия языка, культуры, сознания и коммуникации и дополняют кросс-культурные исследования новыми данными.

Сопоставительные исследования в области культурной семантики, лингвокультурологии, кросс-культурной прагматики, имеют как теоретическое, так и практическое значение. Их результаты находят широкое применение в преподавании иностранных языков, в межкультурной коммуникации и переводческой практике (Bowe et al. 2017, DeCapua \& Wintergerst 2004, Lewis 2019, Pavlovskaya 2021, Savitsky \& Ivanova 2018 и др.).

Состояние современного переводоведения также обсуждалось с акцентом на междисциплинарность, мультидисциплинарность и трансдисциплинарность. Представляя пример использования крупномасштабного исследовательского проекта по эргономике перевода, Гари Масси предлагает 
модель трансдисциплинарного исследования в профессиональных условиях и подчеркивает необходимость перехода от междисциплинарности к трансдисциплинарности. Клавдия Беднарова-Гибова рассматривает перспективы и противоречия современных переводоведческих исследований, связанных с полидисциплинарностью. Несмотря на наличие некоторых противоречий, неопровержимым является тот факт, что переводоведение как наука имеет междисциплинарный характер, что, как отмечает В.В. Сдобников, обусловлено комплексным характером практически всех видов перевода и переводческой деятельности как таковой (Sdobnikov 2019: 323).

Междисциплинарная исследовательская парадигма проявляется не только в сближении лингвистики с другими областями гуманитарного знания, в результате чего появились социолингвистика, психолингвистика, лингвокультурология, когнитивная лингвистика и др., но и в сближении естественно-научного и гуманитарного знания, что породило, например, нейролингвистику, экологическую лингвистику, компьютерную лингвистику, корпусную лингвистику. Исследователи подчеркивают, что сближение различных областей знаний является одним из значимых направлений современной науки (см., например, Sinelnikova 2020).

Использование современных компьютерных технологий и искусственного интеллекта в теоретической и прикладной лингвистике - одно из актуальных и перспективных областей междисциплинарных исследований (Alemi \& Haeri 2020, Fuertes-Olivera et al. 2016, Hirschberg \& Manning 2015, Paris et al. 2013, Rapp et al. 2016). Вопросы проведения лингвистических исследований с применением компьютерных технологий, создание национальных корпусов, участие лингвистов в создании искусственного интеллекта, применение искусственного интеллекта в создании словарей, использование компьютеров и робототехники в образовании и обучении иностранным языкам - это лишь немногие вопросы, которые обсуждались на саммите. Широкий интерес к данному направлению подтолкнул нас к идее подготовить в ближайшей перспективе специальный номер журнала, посвященный компьютерной лингвистике. В этом выпуске мы ограничились статьей Сальвадора Понс Бордериа, посвященной корпусной лингвистике и задаче аннотирования корпусов.

Среди первостепенных по значимости стоит вопрос о миноритарных языках, их современном состоянии и использовании. В настоящее время насчитываются десятки, если не сотни, миноритарных языков и языков в миноритарной ситуации, полноценное и даже символическое функционирование которых затруднено или практически невозможно. Особую проблему представляет собой область языковых прав как отдельной личности, так и коллектива носителей языка (Moskvitcheva \& Viaut 2019, Skutnabb-Kangas 2000, Viaut 2019, 2021). Особую обеспокоенность вызывает проблема исчезновения языков. По данным ученых, никогда еще языки не исчезали так быстро, как в наше время, чему есть социальные, политические, экономические и культурные причины. Глобализация и необходимость lingua franca как средства коммуникации также играют в этом свою роль 
(см. Brenzinger 2007, Crystal 2002, Fishman 2007 и др.). Считается, что только 600 из примерно 6000 существующих языков не подвергаются угрозе исчезновения (Crystal 2002). Данная проблема глубоко волнует не только лингвистов и антропологов. С исчезновением языка теряется и часть культуры, а также знания, которые передавались на этом языке. Для носителей исчезающих языков вопрос сохранения родного языка - это вопрос «идентичности, равенства и социальной справедливости» (Guérin \& Yourupi 2017: 2018).

Процесс исчезновения языков носит глобальный характер и протекает по всему миру, касается он и России (Moskvitcheva 2019, Viaut 2014, 2019, 2021). Можно ли воспрепятствовать этому процессу или хотя бы замедлить его? В нашем выпуске А.А. Кибрик представляет программу сохранения и возрождения языков народов России, предлагаемую Институтом языкознания Российской академии наук, и обосновывает необходимость участия в сохранении языка как с научной, так и гуманитарной точки зрения. В статье рассматриваются различные подходы к разным языковым ситуациям и выдвигаются три необходимых, по мнению автора, условия, которые должны быть соблюдены в любом проекте по ревитализаии языков: участие местных активистов, административная и финансовая поддержка, а также научная методология.

Среди прикладных вопросов, входящих в парадигму «человек - язык культура», следует также отдельно выделить вопросы языковой политики и языкового образования (см., например, Aronin \& Yelenevskaya 2021, Kohonen et al. 2014, Polinsky \& Kagan 2007, Protassova \& Yelenevskaya 2020, Ringblom $\&$ Karpava 2020, Zbenovich 2016). Хотя преподавание иностранных языков не входит в сферу интересов нашего журнала, в этом выпуске мы делаем исключение и предлагаем вниманию читателей две статьи, авторы которых Хино Нобуюки, Мария Еленевская и Екатерина Протасова - выходят далеко за рамки методики и ставят вопросы широкого плана, касающиеся взаимодействия языка, этничности, идентичности, культуры и системы образования, подходов к преподаванию иностранных языков, языковой политики, языковой идеологии и др. Назовем лишь основные.

- Должны ли в век глобализации и в ситуации языкового разнообразия сегодняшнего мира неносители языка подстраиваться под коммуникативные модели носителей языка?

- Не подавляет ли ориентированность на нормы иностранного языка свободу мысли и самовыражения как базовые права человека?

- Как меняется преподавание таких мировых языков, как английский и русский, в связи с признанием того, что их функции и статус в разных странах различны?

- Имеют ли перспективу педагогические методы, направленные на достижение «совершенного» владения изучаемыми языками, или необходимо учитывать местную социолингвистическую ситуацию, потребности студентов и требования рынка труда? 
Нам представляется, что эти вопросы, требующие как методического, так и лингвистического осмысления, никого не оставят равнодушным, потому что они напрямую относятся к молодому поколению, а значит, и к нашему будущему.

Завершают номер две рецензии на книги, созвучные проблемам, обсуждаемым на саммите.

(C) Yulia N. Ebzeeva, 2021 cc) creative commons

This work is licensed under a Creative Commons Attribution 4.0 International License https://creativecommons.org/licenses/by/4.0/

\section{REFERENCES}

Alba-Juez, Laura and Larina, Tatiana. 2018. Language and emotion: Discourse-pragmatic perspectives. Russian Journal of Linguistics 22 (1). 9-37. DOI: https://doi.org/10.22363/ 2312-9182-2018-22-1-9-37

Alemi, Minoo \& Nafiseh S. Haeri. 2020.Robot-assisted instruction of L2 pragmatics: Effects on young EFL learners' speech act performance. Language Learning and Technology 24(2). 86-103

Aronin, Larisa \& Maria Yelenevskaya. 2021. Teaching English in multilingual Israel: Who teaches whom and how: A review of recent research, 2014-2020. Language Teaching. (In print).

Bilá, Magdaléna \& Svetlana V. Ivanova.2020. Language, culture and ideology in discursive practices. Russian Journal of Linguistics 24 (2). 219-252. DOI: https://doi.org/10.22363/ 2687-0088-2020-24-2-219-252

Besemeres, Mary \& Anna Wierzbicka (eds.). 2007. Translating lives: Living with two languages and cultures. St. Lucia: University of Queensland Press.

Bromhead, Helen \& Zhengdao Ye (eds.). 2020. Meaning, Life and Culture: In Conversation with Anna Wierzbicka. Canberra: Australian National University Press.

Bowe, Heather, Kylie Martin \& Howard Manns. 2017. Communication across cultures. Mutual Understanding in a global world. Cambridge: Cambridge University Press.

Brenzinger, Matthias (ed.). 2007. Language Diversity Endangered. Trends in Linguistics. Studies and Monographs 181. Berlin / New York: Mouton de Gruyter.

Brenzinger, Matthias, Arienne M. Dwyer, Tjeerd de Graaf, Colette Grinevald, Michael Krauss, Osahito Miyaoka, Nicholas Ostler, Osamu Sakiyama, María E. Villalón. Akira Y. Yamamoto \& Ofelia Zepeda. 2003. Paris: UNESCO Intangible Cultural Unit, Safeguarding Endangered Languages. http://www.unesco.org/culture/ich/doc/src/00120EN.pdf (accessed 5 May 2021).

Crystal, David. 2002. Language Death. Cambridge. Cambridge University Press. DOI: https://doi.org/10.1017/CBO9781139871549

DeCapua, Andrea \& Ann C. Wintergerst. 2004. Crossing Cultures in the Language Classroom. The University of Michigan Press.

Dewaele, Jean-Marc. 2010. Emotions in multiple languages. Palsgrave Macmillan.

Ebzeeva, Yulia, Natalia Dugalich, Dmitriy Nakisbaev \&Anna Levshits. 2019. Breaking through in Subject Rankings: IMLICaM Experience. Proceedings of ICERI2019 Conference, $11^{\text {th }}-13$ th November 2019, Seville, Spain. 4239-4243. 
Fishman, Joshua A. 1991 Reversing Language Shift: Theoretical and Empirical Foundations of Assistance to Threatened Languages. Clevedon: Multilingual Matters.

Fuertes-Olivera, Pedro A., Sven Tarp \& Peter Sepstrup. 2018. New insights in the design and compilation of digital bilingual lexicographical products: the case of the diccionarios valladolid-UVa. Lexicos 28. 152-176.

Gladkova, Anna. 2019. When value words cross cultural borders: English Tolerant versus Russian Tolerantnyj. Studies in Ethnopragmatics, Cultural Semantics, and Intercultural Communication: Minimal English (and Beyond). 73-93

Gladkova, Anna \& Tatiana Larina. 2018a. Anna Wierzbicka, words and the world. Russian Journal of Linguistics 22 (3). 499-520. DOI: https://doi.org/10.22363/2312-9182-201822-3-499-520

Gladkova, Anna \& Tatiana Larina. 2018b Anna Wierzbicka, language, culture and communication. Russian Journal of Linguistics 22 (4). 717-748. DOI: https://doi.org/10.22363/2312-9182-2018-22-4-717-748

Goddard, Cliff \&Anna Wierzbicka. 2007. Semantic primes and cultural scripts in language learning and intercultural communication. In Sharifian, Farzad \& Gary Palmer (eds.) Applied Cultural Linguistics: Implications for second language learning and intercultural communication, 105-124. Amsterdam: John Benjamins.

Goddard, Cliff \& Anna Wierzbicka. 2021. Semantics in the time of coronavirus: "Virus", "bacteria", "germs", "disease" and related concepts. Russian Journal of Linguistics 25 (1). 7-23. DOI: https://doi.org/10.22363/2687-0088-2021-25-1-7-23

Guérin, Valérie \& Paulina Yourupi. 2017. Language endangerment. In Hiroko Sato and Joel Bradshaw (eds.). Languages of the Pacific Islands: Introductory Readings. Revised and expanded edition. 209-219. https://www.researchgate.net/publication/343602602 Language_endangerment [accessed May 15 2021].

Hirschberg, Julia \& Christopher D. Manning. 2015. Advances in natural language processing. Science 349(6245). 261-266. https://science.sciencemag.org/content/349/6245/261.full .

Kabakchi, Victor V. \& Zoya G. Proshina. 2021. Lexico-semantic relativity and versatility in translation and intercultural communication. Russian Journal of Linguistics 25 (1). 165-193. DOI: https://doi.org/10.22363/2687-0088-2021-25-1-165-193 (In Rus.)

Kecskes, Istvan. 2014. Intercultural Pragmatics. Oxford: Oxford University Press.

Klyukanov, Igor E. \& Leontovich, Olga A. 2016. Russian perspectives on communication. The Handbook of Communication in Cross-Cultural Perspective. 29-41.

Kohonen, Viljo, Riitta Jaatinen, Pauli Kaikkonen \& Jorma Lehtovaara (eds.). 2014. Experiential Learning in Foreign Language Education. London and New York: Routledge.

Larina, Tatiana. 2015. Culture-specific communicative styles as a framework for interpreting linguistic and cultural idiosyncrasies. International Review of Pragmatics 7 (5). Special issue: Communicative Styles and Genres. 195-215.

Larina, Tatiana, Arto Mustajoki \& Ekaterina Protassova. 2016. Dimensions of Russian culture and mind. In Katja Lehtisaari and Arto Mustajoki (eds.). Philosophical and cultural interpreta-tions of Russian modernisation. Series: Studies in Contemporary Russia. London/New York: Routledge. 7-19.

Larina, Tatiana V., Vladimir I. Ozyumenko \& Svetlana Kurteš. 2017. I-identity vs we-identity in language and discourse: Anglo-Slavonic perspectives Lodz Papers in Pragmatics 13 (1). 195-215.

Larina, Tatiana \& Douglas Mark Ponton. 2020.Tact or frankness in English and Russian blind peer reviews. Intercultural Pragmatics 17 (4). 471-496. DOI: https://doi.org/10.1515/ ip-2020-4004

Lewis, Richard D. 2019. The cultural imperative: Global trends in the 21st century. Training, Language and Culture 3 (3). 8-20. 
Mackenzie, J. Lachlan \& Laura Alba-Juez (eds.). 2019. Emotion in Discourse. Amsterdam and Philadelphia: John Benjamins.

Malyuga, Elena. N. \& Michael McCarthy. 2018. English and Russian vague category markers in business discourse: Linguistic identity aspects. Journal of Pragmatics 135. 39-52.

Malyuga, Elena. N. \& Michael McCarthy. 2020. Non-minimal response tokens in English and Russian professional discourse: A comparative study. Voprosy Jazykoznanija 4. 70-86. DOI: 10.31857/0373-658X.2020.4.70-86

Moskvitcheva, Svetlana. 2014. Étendue et limites de la synonymie dans la terminologie désignant les langues minoritaires en russe. In Viaut, A. et Moskvitcheva, S. Catégorisation des langues minoritaires en Russie et dans l'espace post-soviétique. Bordeaux: Maison des sciences de l'homme d'Aquitaine. 21-44.

Moskvitcheva, Svetlana. 2019. Prototypical notions of minority languages in the Soviet Union and Russia: "Native Language" (rodnoj âzyk) and "National Language" (nacional'nij $\hat{a} z y k$ ). In Moskvitcheva, S. and Viaut A. (eds.). Minority Languages from Western Europe and Russia. Comparative Approaches and Categorical Configurations, 49-69. Cham: Springer (Serie Language Policy).

Moskvitcheva, Svetlana \& Viaut, Alain. (eds.). 2019. Minority Languages from Western Europe and Russia. Comparative Approaches and Categorical Configurations. Cham: Springer (Serie Language Policy).

Paris, Cécile L., William R, Swartout \& William C. Mann (eds.). 2013. Natural Language Generation in Artificial Intelligence and Computational Linguistics. New York: Springer Science + Business Media LCC.

Pavlovskaya, Anna V. 2021. National identity in international education: Revisiting problems of intercultural communication in the global world. Training, Language and Culture 5 (1). 20-36. DOI: 10.22363/2521-442X-2021-5-1-20-36

Polinsky, Maria \& Olga Kagan. 2007. Heritage speakers in the 'wild' and in the classroom. Language and Linguistic Compass 1. 368-395.

Protassova, Ekaterina \& Maria Yelenevskaya. 2020. Learning and teaching Russian as a pluricentric language. International Journal of Multilingual Education 15. 111-131.

Rapp, Reinhard, Serge Sharoff \& Pierre Zweigenbaum. 2016. Recent advances in machine translation using comparable corpora. Natural Language Engineering 22 (4). 501-516. DOI: https://doi.org/10.1017/S1351324916000115

Ringblom, Natalia \& Sviatlana Karpava. 2020. Family language policy, Russian language use, maintenance and transmission in Cyprus and Sweden. In Mustajoki, A., Protassova, E. \& Yelenevskaya, Maria (eds.) The Soft Power of the Russian Language: Pluricentricity, Politics and Policies, 237-244. London, New York: Routledge

Savitsky, Vladimir M. \& Aryuna G. Ivanova. 2018. The role of cultural scripts in non-native speech generation. Training, Language and Culture 2 (4). 70-83. DOI: 10.29366/2018tlc.2.4.5

Skutnabb-Kangas, Tove. 2000 Linguistic genocide in education - or worldwide diversity and human rights? Mahwah, New Jersey: Lawrence Earlbaum Associates.

Sdobnikov, Vadim. 2029. Translation studies today: Old problems and new challenges. Russian Journal of Linguistics 23 (2). 295-327 (In Russ.)

Sinelnikova, Lara N. The conceptual environment of the frontier discourse in humanities. Russian Journal of Linguistics 24 (2). 467-492. DOI: https://doi.org/10.22363/26870088-2020-24- 2-467-492 (In Russ.)

Viaut, Alain. 2014. Langue et territoire à travers les notions désignant les langues en situation minoritaire en France et en Russie. In Viaut, A. et Moskvitcheva, S. (eds.). La catégorisation des langues minoritaires en Russie et dans l'espace post-soviétique, 321-338. Bordeaux: Maison des sciences de l'homme d'Aquitaine.

Viaut, Alain. 2019. Reflection on a multidisciplinary approach to "minority languages" as a linguistic object in Europe. In Moskvitcheva, S. \& Viaut, A. (eds.). Minority Languages 
from Western Europe and Russia. Comparative Approaches and Categorical Configurations, 23-33. Cham: Springer (Serie Language Policy).

Viaut, Alain (ed.). 2021. Catégories référentes des langues minoritaires en Europe. Bordeaux: Maison des sciences de l'homme d'Aquitaine.

Wierzbicka, Anna. 1972. Semantic Primitives. Frankfurt: Athenäum.

Wierzbicka, Anna. 1980. Lingua mentalis: The semantics of natural language. Sydney: Academic Press.

Wierzbicka, Anna. 2003/1991. Cross-Cultural Pragmatics: The Semantics of Human Interaction. 2-nd ed-n. Berlin: Mouton de Gruyter.

Wierzbicka, Anna. 2012. Understanding others requires shared concepts. Pragmatics \& Cognition 20 (2). 356-379. DOI: 10.1075/pc.20.2.09wie

Wierzbicka, Anna. 2020. Addressing God in European languages: Different meanings, different cultural attitudes. Russian Journal of Linguistics 24 (2). 259-293. DOI: 10.22363/26870088-2020-24-2-259-293

Zbenovich, Claudia. 2016. Cross-cultural communication in Russian-speaking immigrant families in Israel: Language practices of the second generation. Russian Journal of Linguistics 20 (3). 103-116.

\section{Bionote:}

Yulia N. EBZEEVA, PhD, is Director of the Institute of Modern Languages, Intercultural Communication and Migration of the RUDN University, Adviser for Global Partnerships, Head of the Department of Foreign Languages of the Faculty of Philology. She is a member of the international scientific committee of QS and a member of the editorial board of the Russian Journal of Linguistics. She actively participates in international conferences and forums, has spoken at the Council of Europe, and has repeatedly acted as an expert on linguistic and migration issues. She authored and co-authored over 80 publications. Her research interests include French lexicology and stylistics, translation studies, intercultural communication, sociolinguistics, migration studies, and educational policy.

\section{Contact information:}

Peoples' Friendship University of Russia

6, Miklukho-Maklaya, Moscow, 117198, Russia

e-mail: ebzeeva-jn@rudn.university

ORCID: 0000-0002-0043-7590

\section{Сведения об авторе:}

Юлия Николаевна ЭБЗЕЕВА - директор Института современных языков, межкультурной коммуникации и миграций РУДН, советник по глобальным партнерствам, зав. кафедрой иностранных языков филологического факультета РУДН. Она является членом международного научного комитета QS и членом редколлегии журнала Russian Journal of Linguistics. Принимает активное участие в работе международных и всероссийских конференций и форумов, выступала в Совете Европы, многократно выступала экспертом по лингвистическим и миграционным проблемам. Автор более 80 публикаций. В сферу ее интересов входят лексикология и стилистика французского языка, теория перевода, межкультурная коммуникация, социолингвистика, миграциология, образовательная политика.

\section{Контактная информация:}

Российский университет дружбы народов

Россия, 117198, Москва, Миклухо-Маклая, 6

e-mail: ebzeeva-jn@rudn.university

ORCID: 0000-0002-0043-7590 